\title{
INDICATORS OF VELOPHARYNGEAL INSUFFICIENCY AND THEIR INFLUENCE ON THE CHOICE OF TREATMENT METHOD
}

\section{Shafeta Oleg ${ }^{1}$}

Yakovenko Anna ${ }^{2}$

DOI: https://doi.org/10.30525/978-9934-571-89-3_84

Velopharyngeal insufficiency (VPI) after primary operations on the palate ranges from $5 \%$ to $45 \%$ [2], which is due to the type of cleft, the terms and methods of surgical treatment, the complex of speech therapy correction. To prevent the development of VPI, it is important to choose the tactics of treatment for such children, which requires determining the causes of its development. They are related to the functional capacity of the velopharyngeal complex (VPC), the structural components of which are soft palate, lateral and back of the pharyngeal walls. Study

\footnotetext{
${ }^{1}$ Bogomolets National Medical University, Ukraine

${ }^{2}$ Children Clinical Hospital № 7, Ukraine 
VPC components will enable to carry out planning optimal treatment, such as surgery or speech therapy $[1 ; 3]$.

MRI research was conducted on 15 children after veloplasty and 93 children without pathology aged 5 to 18 years. The most varied indicators of VPC are distinguished, which are divided into 2 groups: anatomical and functional. Functional indicators included the muscles of the VPC and the structural units in which they pass: the ratio of the length of soft palate and the distance from the muscle ligament to the palatine aponeurosis to the posterior pharyngeal wall (Pasavans roller) (VL/VPR), the ratio of the length of the soft palate and the width of the mesopharynx $(\mathrm{VL} / \mathrm{PhW})$. The anatomical parameters were based on the morphological dimensions of the VPC - the ratio of the width and depth of the mesopharynx (PhW/PhD) and the ratio of the distance of muscle placement in the soft palate to the width of the mesopharynx (VID/PhW). The survey's results highlight three groups of children after veloplasty. The first included 5 patients after veloplasty, which showed a decrease in the index to $0,7 \mathrm{VL} / \mathrm{VPR}(\mathrm{N}=3,0 \pm 0,4), \mathrm{VL} / \mathrm{PhW}(\mathrm{N}=1,7 \pm 0,3)$ and to $0,9 \mathrm{PhW} / \mathrm{PhD}(\mathrm{N}=1,6 \pm 0,3), \mathrm{VID} / \mathrm{PhW}(\mathrm{N}=1,4 \pm 0,2)$. In 3 of them it is noted that one of the anatomical parameters is saved while another one is reduced. This indicated anatomical changes in the tissues of the VPC, which directly influenced the violation of its functional status, and needed first surgical treatment and, next, speech therapy correction. After carrying out of reveloplastics the increase of all functional indicators was noted (VL/VPR, VL/PhW) to $7,9(\mathrm{~N}=3,0 \pm 0,4)$ and $2,8(\mathrm{~N}=1,7 \pm 0,3)$ in accordance. In the second group, which included 6 children, a varied combination of changes in both functional and anatomical parameters was revealed. Thus, in 2 children there was a decrease VL/VPR to $2,3(\mathrm{~N}=3,0 \pm 0,4)$ and $\mathrm{PhW} / \mathrm{PhD}$ to 0,8 $(\mathrm{N}=1,6 \pm 0,3)$ in a complex with an increase $\mathrm{VL} / \mathrm{PhW}$ to $3,0(\mathrm{~N}=1,7 \pm 0,3)$, this is indicating a shortened soft palate and an enlarged anatomical depth of the mesopharynx, but compensated by a considerably reduced width of the last one. In 3 children there is a decrease $\mathrm{VL} / \mathrm{PhW}$ to $1,0(\mathrm{~N}=1,7 \pm 0,3)$ in a complex with an increase VL/VPR to $6,1(\mathrm{~N}=3,0 \pm 0,4)$ and $\mathrm{PhW} / \mathrm{PhD}$ to $4,7(\mathrm{~N}=1,6 \pm 0,3)$, which corresponds to the expansion of mesopharynx, along with a significant reduction in its anatomical depth. One child had a reduction VL/VPR to $1,1(\mathrm{~N}=3,0 \pm 0,4)$ with an increase in other indicators, a different combination of indicators indicated the compensated functional capacity of the tissues of the VPC due to the reduction of the width and depth of the mesopharynx. Such children needed initially speech therapy correction, and in the absence of positive dynamics - reoperation with the restoration of tissues of the VPC. In group 3, which includes 4 children, there is a preservation or enhancement of functional VL/VPR fron 3,4 to $6,1(\mathrm{~N}=3,0 \pm 0,4)$, VL/PhW from 1,4 to $2,1(\mathrm{~N}=1,7 \pm 0,3)$ and anatomical $\mathrm{PhW} / \mathrm{PhD}$ from 1,8 to $4,7(\mathrm{~N}=1,6 \pm 0,3), \mathrm{VID} / \mathrm{PhW}$ from 1,3 to $3,4(\mathrm{~N}=1,4 \pm 0,2)$ indicators within the norm, indicating the state of the VPC close to the norm, and required only a certain speech therapy correction aimed at restoring the synchronization of muscle work.

Speech therapy correction as a component of complex treatment of the VPI includes work on the formation and development of speech respiration (differentiation of nasal-mouth breathing, training of strength and duration of oral 
exhalation), kinetic and kinesthetic oral praxis (orofacial myofunctional gymnastics, vibratory massage), with the use of innovative speech therapy technologies.

Speech therapy work on the development of speech respiration used as a preparatory stage for synchronizing the muscles that take part in speech activity affects the strength of phonemes, speech clarity and smoothness. The education of speech respiration becomes especially important in the context of the problem of wide mesopharyngx and short soft palate in children with VPI. For this purpose in the work on training of speech breathing the following speech therapy technologies were used: breathing simulator Rabir TRI-BALL, "nose flute" and "flying ball" [4, p. 232].

The formation of kinetic and kinesthetic oral praxis was carried out in two directions: passive and active. With indicators of short soft palate VL/VPR $<2,6$ and $\mathrm{VID} / \mathrm{PhW}<1,2$ used both passive and active type of speech therapist work (orofacial myofunctional gymnastics). The passive direction foresees work on the use of speech therapy technologies - vibrating massager Z-Vibe with nozzles ARK's Roller and ARK's Soft Brush Tip [4, p. 232], which contributed to muscle loading, improved blood supply to soft tissues. This type of massage helped the patients to restore the kinetics of their own articulation zones. The active direction was aimed at stretching the muscles, increasing the length $\mathrm{m}$. levator veli palatini, $\mathrm{m}$. tensor veli palatini.

With indicators of wide mesophyrx $\mathrm{VL} / \mathrm{PhW}<1,4$ and $\mathrm{PhW} / \mathrm{PhD}<1,3$ the main focus of the active direction was aimed at training the muscles of the constrictor of the pharynx. For this purpose, specially selected orofacial myofunctional gymnastics was used. In addition, the vibromassager was used to enhance the nourishing effect of constrictors of the pharynx Z-Vibe with nozzles ARK's Roller, ARK's Probe Tip and ARK's Preefer Tip [4, p. 232].

The proposed set of speech therapies was tested in 15 children with VPI, divided into 3 groups depending on the parameters of VPC. The effectiveness of speech therapist correction was estimated by the degree of nasal phonemes, which was determined by the volume of the nasal air jet (modified nasal tube with built-in ball) and its area (diagnostic nasal mirror). Indicators were recorded before and after correctional speech therapist work. To assess the degree of nasalization were selected back-loud sounds $(\mathrm{g}, \mathrm{k}, \mathrm{h})$. It is these phonemes that are formed with the complete closure of the root of the tongue and soft palate, and the stream of exhaled air is as strong as possible, which requires synchronized work of constrictors of the larynx. To check the level of nasalization, 5 phrases with varying saturation of back-lingual phonemes were selected. (from one to five repetitions in a phrase). Three levels of nasalization were identified - high, medium and low.

The low level was determined under the condition of repetition of all phrases of the nasal air in the modified nasal tube reaching the level of $0-10 \mathrm{~cm}$, the built-in ball does not rise, and its area on the diagnostic mirror is $1 \mathrm{~cm}^{2}$. The average level - the indicators of the nasal tube $-10-20 \mathrm{~cm}$, the built-in ball does not rise, the area - on the diagnostic mirror $2 \mathrm{~cm}^{2}$. The high level is the level of nasal air $>20 \mathrm{~cm}$, the builtin ball is raised by $0.5-1 \mathrm{~cm}$ upwards, the area is $>3 \mathrm{~cm}^{2}$ (table 1 ). 


\section{Indicators of the level of nasalization in children with VPI before and after correctional speech therapist work}

\begin{tabular}{|c|c|c|c|c|c|c|c|}
\hline \multirow{2}{*}{$\begin{array}{c}\text { The number of } \\
\text { repetitions of } \\
\text { back-lingual } \\
\text { phonemes }\end{array}$} & \multicolumn{3}{|c|}{$\begin{array}{c}\text { before } \\
\text { corrective work }\end{array}$} & \multicolumn{3}{|c|}{ after corrective work } & \multirow{2}{*}{$\begin{array}{c}\text { Wilcoxon } \\
\text { Signed } \\
\text { Ranks Test }\end{array}$} \\
\hline & $\begin{array}{l}\text { high } \\
\text { level }\end{array}$ & $\begin{array}{c}\begin{array}{c}\text { medium } \\
\text { level }\end{array} \\
\end{array}$ & $\begin{array}{l}\text { low } \\
\text { level }\end{array}$ & $\begin{array}{l}\text { high } \\
\text { level }\end{array}$ & \begin{tabular}{|c|}
$\begin{array}{c}\text { medium } \\
\text { level }\end{array}$ \\
\end{tabular} & $\begin{array}{l}\text { low } \\
\text { level }\end{array}$ & \\
\hline $\begin{array}{l}1 \text { repeat of } \\
\text { selected } \\
\text { phonemes }\end{array}$ & 4 & 8 & 3 & 0 & 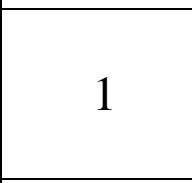 & 14 & $\mathrm{P}<0.01$ \\
\hline 2-3 repeats & 6 & 4 & 5 & 0 & 9 & 6 & $\mathrm{P}<0.01$ \\
\hline$>4$ repetitions & 8 & 3 & 4 & 2 & 8 & 5 & $\mathrm{P}<0.01$ \\
\hline
\end{tabular}

Conducted speech therapy work showed that most of the high level of nasalization occurred in the second group of children, even with one repeat selected phonemes. In the first group, nasalization was more often diagnosed with 2-3 reps of back-lingual phonemes. The level of nasalization was determined mainly by medium and high. Correctional speech therapist work in the first and second groups was conducted in full, including all the outlined stages. As for the third group, the level of nasalization was noted low with the number of repetitions of back-loud sounds was $>4$. With this group, correctional speech therapy work was aimed at strengthening the muscles of constrictors of the pharynx and soft palate. The obtained data confirm the effectiveness of speech therapy work in children with VPI, taking into account the parameters of VPC, namely: VL/VPR, VL/PhW, $\mathrm{PhW} / \mathrm{PhD}$ and VID/PhW, which confirmed the necessity of cooperation of the speech therapist with the maxillofacial surgeon and the preliminary conduct of MRI for the choice of optimal rehabilitation of such children. With complex reduced indicators $\mathrm{VL} / \mathrm{VPR}<2,6 \mathrm{VL} / \mathrm{PhW}<1,4$ $\mathrm{PhW} / \mathrm{PhD}<1,3 \mathrm{VID} / \mathrm{PhW}<1,2$ a repeated surgical intervention on a soft palate with extension of the last and a myoplasty is necessary, after which - a complete speech therapy correction in full. When reduced VL/VPR $<2,6$ and VID/PhW $<1,2$ shows both passive and active type of speech therapy work (orofacial myofunctional gymnastics). With indicators of wide mesophyrinx $\mathrm{VL} / \mathrm{PhW}<1,4$ and $\mathrm{PhW} / \mathrm{PhD}<1,3$ the main emphasis should be directed to training the muscles of the constrictor of the pharynx. In the case of maintaining or enhancing the functional VL/VPR, VL/PhW and anatomical $\mathrm{PhW} / \mathrm{PhD}, \mathrm{VID} / \mathrm{PhW}$ Indicators of rehabilitation of such children are aimed at restoring the synchronization of the work of the muscles of the VPC.

\section{References:}

1. Bhuskute, A., Skirko, J. R., Roth, C., Bayoumi, A., Durbin-Johnson, B., \& Tollefson, T. T. (2017). Association of Velopharyngeal Insufficiency With Quality of Life and PatientReported Outcomes After Speech Surgery. JAMA Facial Plastic Surgery, 19(5), 406. doi:10.1001/jamafacial.2017.0639

2. Yamaguchi, K., Lonic, D., Lee, C.-H., Wang, S.-H., Yun, C., \& Lo, L.-J. (2016). A Treatment Protocol for Velopharyngeal Insufficiency and the Outcome. Plastic and Reconstructive Surgery, 138(2), 290e-299e. doi:10.1097/prs.0000000000002386 
3. Glade, R. S., \& Deal, R. (2016). Diagnosis and Management of Velopharyngeal Dysfunction. Oral and Maxillofacial Surgery Clinics of North America, 28(2), 181-188. doi:10.1016/ j.coms.2015.12.004.

4. Yakovenko A. A. (2014). Innovatsiini tekhnolohii dlia pidvyshchennia yakosti provedennia lohopedychnykh zaniat $\mathrm{v}$ suchasnykh umovakh zahalnoosvitnoho prostoru [Innovative technology to improve the quality of the speech training in modern conditions of the common educational space]. Scientific journal of National Pedagogical Dragomanov University, vol. 19, no 27, pp. 231-234. 